\title{
Toward a behavioral approach of international shipping: a study of the inter- organisational dynamics of maritime safety
}

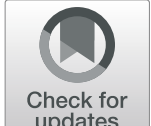

François Fulconis ${ }^{1}$ and Raphael Lissillour ${ }^{2^{*}}$ (D)

\author{
* Correspondence: raphael. \\ lissillour@outlook.com \\ ${ }^{2}$ IPAG Business School, PostDoc at \\ the École Polytechnique (i3-CRG), \\ Paris, France \\ Full list of author information is \\ available at the end of the article
}

\begin{abstract}
Classification societies play a major role in maritime safety and the regulation of the international shipping market. They have a dual mission, namely the classification and certification of ships. Paradoxically, the academic literature on the strategic behaviour of classification societies remains very limited. More often than not, the scope of prior research has been limited to the definition of their missions in the shipping ecosystem with an emphasis on their changing legitimacy as maritime accidents occur. Consequently, this paper aims at providing a better understanding of the specific role of classification societies in maritime safety and within the interorganisational dynamics of international shipping. The study is based on a conceptual framework provided by the behaviourist approach and applied to the inter-organisational dynamics of supply chains. This approach enables in-depth analysis of actors' strategic behaviours by focusing on four dimensions: power, leadership, conflict and cooperation. The main results highlight the increasingly central and paradoxical role of classification societies. This role encompasses, on the national level, classification and certification processes, and, on the supranational level, the creation of new rules and regulations. The study highlights the importance of their ability to master the official framework and institutional vocabulary, which enable them to strengthen their power and leadership in the shipping market. This capacity helps them to limit conflicts between actors and to encourage certain cooperative behaviours based on relationships of dependence and interorganisational interdependence.
\end{abstract}

Keywords: Behaviourism, Classification societies, International shipping, Maritime safety

\section{Introduction}

Classification societies play a major role in the functioning of the international maritime market. Created during the eighteenth century, they established and published rules (technical and administrative) for ships in the project phase, under construction or operation. Thus, they have a dual mission of classifying and certifying ships. In this context, they are asked by shipowners to verify that a vessel, throughout its life, meets its regulations. While overtly their activities are responsible for private contracts with

(c) The Author(s). 2021 Open Access This article is licensed under a Creative Commons Attribution 4.0 International License, which permits use, sharing, adaptation, distribution and reproduction in any medium or format, as long as you give appropriate credit to the original author(s) and the source, provide a link to the Creative Commons licence, and indicate if changes were made. The images or other third party material in this article are included in the article's Creative Commons licence, unless indicated otherwise in a credit line to the material. If material is not included in the article's Creative Commons licence and your intended use is not permitted by statutory regulation or exceeds the permitted use, you will need to obtain permission directly from the copyright holder. To view a copy of this licence, visit http://creativecommons.org/licenses/by/4.0/. 
shipowners, their role is much more complex to grasp since it is of interest to many other players directly or indirectly linked to the maritime transport market. These players include insurers, charterers, shippers, bankers, potential buyers of ships, states (flag, port, coastal) for which they can carry out checks, the European Union, the European Maritime Safety Agency (EMSA), the International Maritime Organisation (IMO), amongst others.

Bindel (2019), general engineer of armaments, expert-approved by the French Court of Cassation and a member of the Marine Academy, offers a synthetic presentation of classification societies. He states that "it was in London, in the mid-18 $8^{\text {th }}$ century, that marine insurers first felt the need to rely on an independent company to assess the strength of the vessels they guaranteed. The first register of listed ships, Lloyd's Register Book, was published for the years 1764-1765 and 1766". Since then, this profession has continued to develop and, according to Bindel (2019), in "almost two and a half centuries, classification societies have evolved [...] but the founding principles remained the same. A classification company is first and foremost an organisation that establishes rules, both technical (regarding, for a ship, its hull, its machinery and its equipment) and administrative (frequency and scope of inspections for example), and publishes them." The classification societies provide their services to shipowners for the vessels in service and the vessels under construction. The classification society will then verify that a particular vessel conforms with its standards and issue a published certificate. The classification society proceeds to periodical verification to ensure that the vessel continues to meet its standards. Classification is, therefore, a private matter, a contract between a service provider and a shipowner. However, the class certificate "may also be of interest to third parties, insurers, charterers, bankers or potential buyers" Bindel (2019).

To date, there are approximately 50 classification societies in the world. Since 1968, the largest of them (representing 94\% of the international merchant fleet tonnage) have been grouped within the International Association of Classification Societies (IACS). As an international non-governmental organisation, IACS plays an important role in self-regulating the maritime market by harmonising rules and practices to increase maritime safety (Molenaar, 2014; Kopela, 2017; Ceyhun, 2020; Lissillour et al., 2021a, b). In addition to their private classification activity, classification societies carry out a public service mission on behalf of the flag states known as 'certification'. They act on behalf of states that generally do not have the means to carry out inspections or audits (of the ship and the company that manages it) on terms depending on each flag state. Furthermore, classification societies must ensure compliance of vessels, not with the rules they have issued, but with the technical standards of various international conventions relating to personal safety (the Safety of Life at Sea (SOLAS) Convention) or pollution (the Marine Pollution (MARPOL) Convention) (Raynaut, 2019). Their role here is all the more justified since these inspections are identical to those carried out in the context of classification.

However, in a world where economic interests and safety imperatives are entwined, their credibility can be questionable. According to Latrech (2004), several factors justify this questioning: the ambiguity of their role between public and private, their commercial nature, sometimes their complacency, their financial dependence on shipowners, the legal problem posed by the disclaimer inserted in their contracts, or the IACS 
policy excluding smaller companies. Furthermore, from a legal viewpoint, their responsibility in strengthening maritime safety is regularly asked (Ferrer, 2004; Langlais, 2018; Raynaut, 2019). However, beyond the legal issues, is it not the broader governance of maritime safety in which classification societies play a particular role that needs to be questioned? As Latrech (2004) pointed out, "moving from a simple information role to a more technical role, they are now wandering between private functions for the granting of a rating and public functions carried out under delegation of flag states to equip ships with their international safety titles".

Nevertheless, while their role is increasingly crucial for the regulation and safety of the maritime market, the academic literature on the strategic behaviours of the stakeholders, the forefront of which are classification societies, remains very limited. Most prior research on maritime safety focused on the technical aspects and identifying risk indicators to predict accidents; the subject raises issues related to strategic management and supply chain management (SCM) (Kretschmann, 2020). Nevertheless, it remains very understudied in Management Sciences (Lissillour et al., 2019), and recent studies urge future research to focus on the inter-organisational aspects of maritime safety (Dominguez-Péry et al., 2021). Furthermore, whereas prior research focused on decision models based on a rational decision-making approach (Hoffmann et al., 2020; Rahman et al., 2016), this research use behaviourism to understand better stakeholders' complexity, their power relationships, leadership, conflict and cooperation maintained with their market, in a duality oscillating between regulatory actions and competitive behaviour.

In order to do so, this paper adopts the analysis prism of the behaviourist approach commonly applied to the inter-organisational dynamics of supply chains. Specifically, the paper aims to investigate the role of classification societies in maritime safety governance and the inter-organisational dynamics of international shipping. To do so, we mobilise the dimensions of power, leadership, conflict and cooperation characterising the behaviourist approach. The second section is dedicated to the literature review. Referencing works analysing the inter-organisational dynamics of supply chains, the third section develops the theoretical framework and analysis grid used in this study. The fourth section details the empirical study's main methodological features between 2014 and 2019 in the port areas of Shanghai, Singapore, and Europe. The fifth section is devoted to the presentation and discussion of the main research findings. Finally, while acknowledging this work's limitations, we conclude by elaborating on the practical and theoretical contributions and venue for further research.

\section{Literature review}

The classification societies have been studied from various perspectives, first in terms of methodology and focus. The classification societies play an important role in the functioning of the Port State Control (PSC) because "the flag of registry and classification society are an integral part of the target factors used by PSC authorities when deciding on vessels to select for inspection" (Cariou and Wolff, 2011). The impact of the flag of registry on the casualty rates has been measured to assess the performance of Flags of Convenience compared to the others ( $\mathrm{Li}$ and Wonham, 1999; Alderton and Winchester, 2002). Other research studies included other variables, such as the ship's age (Robert and Marlow, 2002) and size and type 
(Talley, 1999). Cariou et al. $(2007,2008)$ considered all these variables together and confirmed that they are potent predictors of eventual deficiencies during the inspection. Knapp and Franses (2007b) investigated the phenomena of flag and classhopping and measured the extent to which both contribute to increasing vessels' blacklisting. Indeed, vessels in bad shape are more likely to repeatedly engage in flag- and class-hopping (Cariou and Wolff, 2011).

Prior studies investigated the regional impact of the maritime safety regime on the shipping industry. Port State Control inspections have been found to have a positive effect on cost-saving for the industry as it reduces the risk of detention and loss of ships (Knapp et al., 2011). But then, how to avoid unnecessary inspections (Bijwaard and Knapp, 2009) and target the right ships is the rationale behind the work of Knapp and Franses (2007a, b). Via econometric analysis, the authors found out that the basic ship profiles did not vary much across regimes regarding detention probability (Knapp and Franses, 2007b). In another study, these authors found out that a high detention rate did not lead to a low casualty rate, thus pointing at the lack of coordination and trust amongst PSC regimes and industry inspections (Knapp and Franses, 2008). This lack of trust between stakeholders such as states, classification societies, insurance companies and shipowners has created a fertile environment for many inspections providers for the sake of safety (Knapp and Franses, 2010). Meanwhile, other factors outside the reach of the PSC, such as the economic conditions of the shipping market, may negatively impact safety quality (Knapp and Franses, 2010).

Beyond these essentially quantitative studies, investigations from the field of engineering have led scholars to create a systematic management tool to prevent marine accidents by good design, training, and operation (Wang, 2001). While having a strong potential for useful translation into the industrial setting, these studies do not lead to an acute understanding of the inter-organisational dynamics to which this paper is devoted. A few studies from the field of supply chain management tackled the case of classification societies. Goh and Yip (2014) documented their essential role for maritime safety, despite being sometimes suspected of partiality because of their commercial relationship with the shipowners and the competition amongst societies. Early publications already stressed the danger of privatisation of maritime safety and the need for governmental audit and monitoring on classification societies (Brooks, 1996). Recent interdisciplinary studies at the crossroad between sociology and management drew on the theory of practice to better understand the growing domination of classification societies (Lissillour and Bonet-Fernandez, 2020) as they impose their vision of the world in the governance of maritime safety (Lissillour et al., 2021a, b) while other actors are gradually excluded (Lissillour and Bonet, 2018). While these research papers shed much light on the conflict of interest and the source of influence within this ecosystem, their theoretical perspective did not integrate the complexity of both competitive and cooperative relations. This matter of fact motivated the behaviourist approach's choice (Simon, 1947) for this investigation.

\section{Conceptual framework}

The behaviourist approach supports our theoretical framework (Simon, 1947; March and Simon, 1958; Cyert and March 1963), which was applied to distribution channel analysis (Stern and El-Ansary, 1977) and, more broadly, to the study of the inter- 
organisational dynamics of supply chains (Mentzer et al., 2001). Although distinct disciplines approach the distribution channel and supply chain, they are inter-organisational exchange systems with strong conceptual proximity (Roveillo, 2015; Fulconis and Roveillo, 2017). The traditional theories used to study supply chains, more often than not, assume a rational decision-making approach (Gino and Pisano, 2008), which is characterised by 1) the possession of comprehensive data, 2) optimal data analysis taking into consideration alternative actions, and 3) the selection of the most efficient decision to optimise profit (Mantel et al., 2006).

Indeed, decisions are gradually understood not necessarily as the result of a rational process but as bounded by decision-makers capacity to gather and analyse complex data (Mantel et al., 2006). Such complex analysis requires multiple dimensions (DavisSramek et al., 2018), which result from organisational constraints, prior experiences, associative learning (Kaufmann et al., 2014, 2017) and intuition (Salas et al., 2010). According to the Behaviourist School of distribution channel analysis, inter-organisational dynamics are traditionally based on four dimensions: power, leadership, conflict and cooperation (Stern and El-Ansary, 1977). These are regularly used to study the management of multi-actor supply chains (Paché and Spalanzani, 2007; Bonet-Fernandez and Boissinot, 2012; Roveillo, 2015). These will be presented and drawn on to propose an exploratory analysis grid hereafter.

\section{Power}

The dimension of power has been the subject of much work which broadly defines the capacity for influence (Filser, 1989; (Filser et al., 2012). Schopler (1965) defines the power of an individual A over another individual B "as the probability of $B$ engaging in a certain behaviour after an A intervention, compared to B's likelihood of adopting that behaviour in the absence of A's approach". According to the founding work of French and Raven (1959), power is characterised by five sources: reward, sanction, expertise, reference value and legitimacy. For Emerson (1962), power "implicitly resides in dependence on others", which is proportional to resource needs and inversely proportional to the availability of these resources. Porter (1986) determines a company's bargaining power through the level of concentration of its customers and suppliers, its size, and its offer's scarcity or specificity. As for Cox (2001), the author stipulates that, within the framework of supply chains, the power that a company has, originates in 1) the appropriation of value that allows the company to sustain its activity, 2) the contribution of value to the end customer when marketing a product or service, and 3) in the capacity to improve processes between members of the supply chain (Lavastre et al., 2016).

\section{Leadership}

Leadership is defined as the exercise of power "recognised and accepted by members of a group. The legitimacy of the leader allows members to benefit more from the coordination established by the leader. Recognition of leadership is based on members' representation of the leader's vision, legitimacy, and skill/expertise" (Fabbe-Costes, 2010). According to Bowersox and Closs (1996), supply chains need a leader to establish performance-generating cooperation between the various players. One member's 
leadership is due to its power and dominant position (size, the scope of activities, client portfolio, among other issues) and status as a promoter of relations between members.

As proposed by Bonet-Fernandez and Boissinot (2012), for Defee et al. (2010), supply chain leadership is "a relational concept involving a supply chain leader and one or more followers who interact in a dynamic process of mutual influence". The leader is the actor best able to "deploy the four elements of leadership in relation to other members (an organisation capable of greater influence, clearly identifiable by its behaviors, creating visions and establishing relationships with other supply chain organisations" (Defee et al., 2010). The leader then played a central role in managing the supply chain (Ellram and Cooper, 1990).

\section{Conflict}

According to Filser (1989), the dimension of conflict is described either as a state or as a process. Filser (1989) cites Goldman (1966), for whom the conflict is "a social relationship between two or more agents in which at least one of the agents perceives another agent as an adversary whose behaviour is likely to prejudice him". For Bowersox et al. (1980), the causes likely to trigger conflict are both the divergence of objectives and the strategic choices for achieving those objectives. Bonet-Fernandez (2008) states that "logistics do not escape a dimension of vertical competition" and that the strategic level "remains marked by obvious or latent conflicts regarding the sharing of costs and benefits related to the management of logistics operations, but also to the information needed to control flows".

Angelmar and Waldman (1975) identify five resolution methods, namely negligence, accommodation, domination, compromise and cooperation. According to these authors, even if tensions are reduced between companies, conflicts can remain latent. In analysing inter-organisational relations and supply chain management, Cox (1999) followed this logic while focussing more on resolution via domination. Drawing on March and Simon (1958) work, Dant and Schul (1992) propose four conflict management strategies: joint problem-solving, persuasion, negotiation, and the use of thirdparty mediation. While the first two strategies are carried out within a relationship of trust between the actors, the remaining two occur within a situation of mistrust. Finally, any conflict leads either to a breakdown in relations between the actors or the maintenance of relations requiring a renegotiation of the relationship beforehand. Therefore, for Dant and Schul (1992), conflicts should disappear when stakeholders share a mutual will. This conception is similar to Christopher's (1992) approach to inter-organisational relations and supply chain management. A 'win-win' logic is conceivable for the latter because competitive stakes are no longer positioned between companies but between supply chains.

\section{Cooperation}

The logic of cooperation is defined as a strategic approach to coordinating the actions of legally and financially independent companies (Koenig, 1996; Filser, and des Garets, V. and Paché, G., 2012). It brings together three main types of cooperative approaches identified and analysed in strategic management by many authors since the early 1990s. These include 'outsourcing partnerships' which 
correspond to established cooperation between a client and their supplier; 'symbiotic partnerships' which correspond to cooperation developed between companies which "previously had no competitive relationships or customer-to-supplier relationships", and 'strategic alliances' which correspond to cooperation between direct competitors (Garrette and Dussauge, 1995; Koenig, 1996).

Regarding supply chains, Dornier and Fender (2001) highlight the major characteristics of logistics cooperation: a relational dimension in the form of a continuous process of repetitive activities over a considerable period; the pursuit of common goals leading to profit-sharing and the creation of specific assets; partner equality (the give-and-take principle); a posture based on the wealth of shared information and the development of a relationship of trust; and above all, a search for overall performance, if need be, purely in terms of logistics. Therefore, cooperation can be limited to exchanging operational information or deployed using operational and strategic information shared by partners following the same strategy.

\section{Analysis grid and methodological framework}

This section presents the analysis grid developed for this research and describes the qualitative approach.

\section{A specific grid to analyse the role of classification societies}

By favouring a behaviourist approach, the theoretical framework specifically dedicated to analysing distribution channels and the inter-organisational dynamics of supply chains highlights how actors' strategic behaviours engaged in a collective project can be understood according to four dimensions. These were used to develop an analysis grid (Table 1) to understand better the role of classification societies in the international shipping market's functioning. The outstanding features and indicators prevailed over their completeness. In their current state, these indicators are meant to be qualitative and thus not objectively measurable. Depending on the results obtained, the indicators could be further refined and transformed into quantitative indicators, which would lead to a better understanding of the features.

Our analysis grid forms the framework of the interview guide used in this empirical study. This guide is used to collect and produce observational data by facilitating the field confrontation of four theoretical proposals. The links between the theoretical framework and the empirical study were developed using the four dimensions previously highlighted by the theoretical framework and are formulated as follows:

Theoretical Proposition 1: with their power, classification societies occupy a central place in the governance of international maritime safety;

Theoretical Proposition 2: with their leadership, classification societies play a special role in the functioning of the shipping market;

Theoretical Proposition 3: in conflicts occurring between players in the shipping market, classification societies are the ideal actors to manage and resolve them;

Theoretical Proposition 4: in cooperation between players in the maritime transport market, classification societies facilitate their management and coordination of activities. 
Table 1 Analysis grid of the role of classification societies in the international shipping market

\begin{tabular}{|c|c|c|}
\hline $\begin{array}{l}\text { DIME } \\
\text { NSIONS }\end{array}$ & INDICATORS & FEATURES \\
\hline \multirow[t]{3}{*}{ Power } & $\begin{array}{l}\text { Reward } \\
\text { Sanction }\end{array}$ & $\begin{array}{l}\text { The ability of classification societies to influence [French and } \\
\text { Raven (1959), Filser (1989), Filser, and des Garets, V. and Paché, } \\
\text { G. (2012)] }\end{array}$ \\
\hline & $\begin{array}{l}\text { Need for resources } \\
\text { Availability of resources }\end{array}$ & Level of information resource dependency [Emerson (1962)] \\
\hline & $\begin{array}{l}\text { Value-added appropriation } \\
\text { Value-added contribution }\end{array}$ & $\begin{array}{l}\text { Value-added level of classification company services [Porter } \\
\text { (1986), Cox (2001)] }\end{array}$ \\
\hline \multirow[t]{3}{*}{ Leadership } & $\begin{array}{l}\text { Expertise } \\
\text { Legitimacy } \\
\text { Creation of a common vision }\end{array}$ & Recognition by third parties [Defee (2010), Fabbe-Costes (2010)] \\
\hline & $\begin{array}{l}\text { Size } \\
\text { Span of activities } \\
\text { Customer portfolio }\end{array}$ & Weight of the leader [Bowersox and Closs (1996)] \\
\hline & $\begin{array}{l}\text { Position in the network } \\
\text { (central, peripheral) } \\
\text { Coordination of activities } \\
\text { Central role vs satellites }\end{array}$ & $\begin{array}{l}\text { Leader's position [Ellram and Cooper (1990), Defee (2010), } \\
\text { Lavastre et al., (2016)] }\end{array}$ \\
\hline \multirow[t]{3}{*}{ Conflict } & $\begin{array}{l}\text { Divergent objectives } \\
\text { Divergent strategies }\end{array}$ & Causes [Bowersox et al. (1980), Bonet-Fernandez (2008)] \\
\hline & $\begin{array}{l}\text { Negligence } \\
\text { Accommodation } \\
\text { Domination } \\
\text { Compromise } \\
\text { Cooperation }\end{array}$ & Resolution methods [Angelmar and Waldman (1975)] \\
\hline & $\begin{array}{l}\text { Joint strategies } \\
\text { Persuasion } \\
\text { Negotiation } \\
\text { Mediation } \\
\text { Functional or dysfunctional } \\
\text { outcomes }\end{array}$ & Management Strategies [Dant and Schul (1992)] \\
\hline \multirow[t]{3}{*}{ Cooperation } & $\begin{array}{l}\text { Outsourcing partnership } \\
\text { Symbiotic partnership } \\
\text { Strategic alliance }\end{array}$ & Types of cooperative approaches [Garrette and Dussauge (1995)] \\
\hline & $\begin{array}{l}\text { Continuous process of } \\
\text { repetitive activities } \\
\text { Common goals and specific } \\
\text { asset creation } \\
\text { Win-win logic } \\
\text { Performance search }\end{array}$ & Major features [Dornier and Fender (2001)] \\
\hline & $\begin{array}{l}\text { Simple (operational) } \\
\text { coordination } \\
\text { Partial cooperation } \\
\text { (operational and tactical) } \\
\text { Cooperation accomplished } \\
\text { (operational to strategic) }\end{array}$ & Modes of cooperation [Dornier and Fender (2001)] \\
\hline
\end{tabular}

Source: adapted from Fulconis and Roveillo (2017)

\section{A qualitative deductive method}

We adopted a qualitative deductive methodology (Denzin and Lincoln, 2017) to assess the four theoretical propositions based on a qualitative dataset. This methodology is based on in-depth analysis and the search for theoretical rather than statistical representativeness. Data was collected during the 2014-2019 period to allow for a longitudinal analysis of the topic. Data collection used three main methods: semi-structured interviews, direct observation and a focus group. The collection and analysis of these three types of data allowed us to benefit from methodological triangulation, enabling us to account for the complex interactions between actors. Interviews were crucial for 
gather qualitative data that can help us understand the decision making processes. The interviews were semi-structured based on an interview guideline, which allowed participants to let participants speak about the phenomena while giving the interviewer a general orientation based on the theoretical framework. The interview guideline was based on the analysis grid (see Table 1).

During the reporting period, 23 interviews were conducted face-to-face with officials from a dozen major players in international shipping, namely classification societies (CS), shipowners (SO), port and governmental authorities (MPA), logistics service providers (LSP), shipyards (SY), brokers (BK), professors and experts (EXP) (Table 2). As the study was initiated in Asia, these players were mainly located in Shanghai and Singapore and later in Europe. They represented classification societies, shipowners, port and ministerial authorities, logistics service providers, states and other players in the maritime market (shipyard, broker, expert). Most interviews took place in Europe and Asia, more specifically in France and the United Kingdom, and in China and Singapore. France has been selected for easier access to industrial actors such as a shipyard (Saint-Nazaire), port authorities (Toulon), and Bureau Veritas (CS in Paris). China accounts for the world's biggest ports, and Shanghai has been selected for its relevant location and because it is with Singapore the world's two biggest port. Moreover, easier access to the industry was considered favourable in selecting Shanghai as the main research location.

On the other hand, interviews have also been conducted outside Shanghai, notably with a shipowner in Hong-Kong and the port authorities of Jiangsu. The direct observation of the practices of interviewees and their usual working environment enabled a better contextualisation of the data collected during the interviews. Secondary sources have also been used as confirmative or informative data. They concerned mainly articles from the economical press and resource websites such as those of the International Maritime Organisation (IMO), the International Chamber of Shipping (ICS) and IACS. These secondary sources have not been exploited for their scientific value but illustrate the formalisation of conflicts between clearly identified stakeholders. Legal decisions often reveal the balance of power between the players involved.

The focus group was carried out in Shanghai in 2016 with a dozen respondents from the maritime industry. Three groups of actors were selected to gather their contrasting opinions: shipowners, logistics service providers and port representatives. An open environment was created around the same table to encourage participants to openly discuss their perception of classification societies' role in maritime safety. Before the exchanges, a 10-theme guide had been prepared to clarify and supplement the data collected during the interviews and following analyses of secondary sources. During the focus group discussion, the intention was to remain as open and adaptable as possible to the participants' feedback. In order to establish a favourable atmosphere for exchanges, the first topics discussed were fairly easy and general. The themes that followed were increasingly technical and precise. To ensure optimal dynamics, open and closed questions were successively used (see appendix).

Data analysis was based on coding, which involved dissecting data according to initial codes from our theoretical framework. These initial codes correspond to the four main categories of power, leadership, conflict and cooperation which were further divided into sub-categories (the indicators from Table 1), allowing for a manual analysis of the verbatim. 
Table 2 Characteristics of interviewees

\begin{tabular}{|c|c|c|c|c|}
\hline INDUSTRY & POSITIONS & AFFILIATIONS & $\begin{array}{l}\text { HEAD } \\
\text { QUARTERLOCATION }\end{array}$ & CODING \\
\hline $\begin{array}{l}\text { Classification } \\
\text { society }\end{array}$ & $\begin{array}{l}\text { IMO Permanent } \\
\text { Representative }\end{array}$ & Bureau Veritas & France & CSA \\
\hline $\begin{array}{l}\text { Classification } \\
\text { society }\end{array}$ & $\begin{array}{l}\text { Manager for business } \\
\text { development }\end{array}$ & RINA Shanghai Office & China & CSB \\
\hline $\begin{array}{l}\text { Classification } \\
\text { society }\end{array}$ & $\begin{array}{l}\text { IMO Permanent } \\
\text { Representative }\end{array}$ & $\begin{array}{l}\text { International Association of } \\
\text { Classification Societies }\end{array}$ & United Kingdom & $\operatorname{CsC}$ \\
\hline Shipowner & Vice-CEO & $\begin{array}{l}\text { Phoenix Long Navigation } \\
\text { Company, Department of } \\
\text { Maritime Logistics }\end{array}$ & China & $\mathrm{SOA}$ \\
\hline Shipowner & Director & $\begin{array}{l}\text { China Merchants Energy } \\
\text { Shipping Co., Ltd. }\end{array}$ & Hong Kong & SOB \\
\hline Port Authority & $\begin{array}{l}\text { Deputy Director of the } \\
\text { Maritime Division }\end{array}$ & Maritime and Port Authority & Singapore & MPAA \\
\hline Port Authority & President & $\begin{array}{l}\text { Jiangsu Jiangyin Port Group } \\
\text { Co, Ltd. }\end{array}$ & China & MPAB \\
\hline Port Authority & Executive Vice President & $\begin{array}{l}\text { Jiangsu Jiangyin Port Group } \\
\text { Co, Ltd. }\end{array}$ & China & MPAC \\
\hline Port Authority & $\begin{array}{l}\text { Driver, French pilot trade } \\
\text { union }\end{array}$ & Port of Toulon & France & MPAD \\
\hline Port Authority & Port Master & Port of Antwerp & Belgium & MPAE \\
\hline Port Authority & Director of Operations & Port of Antwerp & Belgium & MPAF \\
\hline $\begin{array}{l}\text { Ministerial } \\
\text { Authority }\end{array}$ & Policy Advisor & Belgian state & Belgium & MPAG \\
\hline $\begin{array}{l}\text { Logistics } \\
\text { Service } \\
\text { Provider }\end{array}$ & $\begin{array}{l}\text { Shanghai Branch Vice } \\
\text { President }\end{array}$ & $\begin{array}{l}\text { Zhongyuan Engineering and } \\
\text { Logistic Ltd. }\end{array}$ & China & LSPA \\
\hline $\begin{array}{l}\text { Logistics } \\
\text { Service } \\
\text { Provider }\end{array}$ & Managing Director & $\begin{array}{l}\text { Shanghai Pegasus Logistics } \\
\text { Co, Ltd. }\end{array}$ & China & LSPB \\
\hline $\begin{array}{l}\text { Logistics } \\
\text { Service } \\
\text { Provider }\end{array}$ & Managing Director & $\begin{array}{l}\text { Huyang International } \\
\text { Logistics Co Ltd. }\end{array}$ & China & LSPC \\
\hline $\begin{array}{l}\text { Logistics } \\
\text { Service } \\
\text { Provider }\end{array}$ & Managing Director & $\begin{array}{l}\text { Shanghai Winwell } \\
\text { International Logistics Co. } \\
\text { Ltd. }\end{array}$ & China & LSPD \\
\hline $\begin{array}{l}\text { Logistics } \\
\text { Service } \\
\text { Provider }\end{array}$ & Managing Director & $\begin{array}{l}\text { Huyang International } \\
\text { Logistics Co. Ltd. }\end{array}$ & China & LSPE \\
\hline $\begin{array}{l}\text { Specialised } \\
\text { Logistics } \\
\text { Service } \\
\text { Provider }\end{array}$ & Managing Director & $\begin{array}{l}\text { Shanghai Tongyin } \\
\text { Petrochemical Co. Ltd. }\end{array}$ & China & LSF \\
\hline $\begin{array}{l}\text { Specialised } \\
\text { Logistics } \\
\text { Service } \\
\text { Provider }\end{array}$ & President & $\begin{array}{l}\text { Shanghai Yunze Chemical } \\
\text { Logistics Development Co. } \\
\text { Ltd. }\end{array}$ & China & LSPG \\
\hline Shipyard & Sales Manager's Services & STX France SA & France & SYA \\
\hline Broker & $\begin{array}{l}\text { President and General } \\
\text { Manager }\end{array}$ & Join Ocean Shipbrokers Ltd. & China & BKA \\
\hline Expert & $\begin{array}{l}\text { Former Director of CRET-LOG, } \\
\text { Transport and Logistics Re- } \\
\text { search Centre }\end{array}$ & Aix-Marseille University & France & EXPA \\
\hline Expert & Logistics Professor & Business School & France & EXPB \\
\hline
\end{tabular}




\section{Key results and discussion \\ Power}

For the dimension of power, the analysis of declarative data was structured according to three groups of indicators (see Table 1): (1) ability to influence classification societies (reward, sanction), (2) level of dependence on information resources (need vs availability), (3) level of the added value of the services of classification societies (appropriation and contribution of added value). The associated verbatim are presented by category of actors.

\section{Ability of classification societies to influence}

The relationship between classification societies and shipowners appears asymmetrical. While classification societies can reward the quality of vessels, shipowners are not in a position to sanction the veracity of the classification. According to shipowners interviewed in Shanghai, "classification societies have the right to deny a shipowner the right to operate a ship internationally" (SOA, Shipowner). This is reported by the trade press, which confirms that "no charterer will risk giving goods to an unclassified vessel, and that vessel would no longer have any value in the cargo market or on the used vessel market" (Marasi News, 2017). On the other hand, this preponderance is undermined because large shipowners have strong bargaining power (Goh and Yip, 2014). Indeed, they benefit from the possibility to change the flag of registry of a vessel and the classification society if it is in their interest (Cariou and Wolff, 2011).

States may or may not recognise a classification company as a Recognised Organisation, allowing it to carry out ships' statutory control. The IMO can put pressure on classification societies, particularly in the wake of maritime disasters, to develop their standards. Indeed, according to a former classification company executive, "general pressure through IMO, in particular following a series of accidents (as those with bulk carriers) or outstanding singular events with high profile, is one of the prime movers for this development" (Hormann, 2006). The verbatim interview transcripts converge to illustrate the variety of situations observed and the permanence of asymmetry in the power relationship between classification societies and other supply chain players.

\section{Level of information resource dependence}

In the established power relationship, classification societies cooperate to share information to varying degrees depending on the partner. Indeed, "classification societies have a long-term relationship with their shipowners' clients, so they are more available to shipowners than to other players, especially shipyards. In particular, classification societies offer information and training sessions for logistics companies, not just shipowners." Moreover, "if the shipowner says 'no I don't see it that way', then it is rare that the classification company will favors the shipyard that has placed the order!" (SYA, Shipyard).

As a result, supply chain companies depend on classification companies for their knowledge of maritime safety. According to a group discussion with logisticians in the Shanghai area, "all classification societies provide many training courses, which are very expensive, especially about new regulations. They award certificates, sometimes for the individuals who participate, and mostly certify companies" (Focus Group LSP). While 
states generally need the assistance of classification societies during IMO maritime safety debates, their availability is limited. Indeed, according to a professional of classification societies, "every national delegation has people from the administration, and invites people from classification societies when it has them within its reach... They are always takers, there is no problem" (CSA, Classification Society). This result highlights how information is shared: scarcity and significant commercial value.

The active participation of classification societies in IMO meetings enables them to have early access to first-hand information. In addition, the technical knowledge of classification societies is crucial to the development of regulations. According to one respondent, classification societies are "very close to what happens in terms of regulations. [...] If you are very close to what is happening, if you are in the working groups, then you are informed first and you also have influence" (CSA, Classification Society). This underlines the preponderance of classification societies in the press-justified news channel which confirms that "data, information and advice are so vital for adopting various safety conventions" (Marasi News, 2017). By collecting data at the source, classification societies have all the elements needed to be proactive in developing international standards and maintaining their dominant position.

\section{Value-added level of classification society services}

While the classification certificate is crucial for shipowners, large shipowners also have significant weight in possible negotiations with classification societies. $70 \%$ of the professionals surveyed agreed that "it is sometimes uncomfortable for classification societies to cancel the classification or bother a big client" (SOA, Shipowner). The results indicate that the power of classification societies is contained by a more balanced power relationship with large clients.

However, classification societies are given the mandate to act on behalf of states to comply with their statutory obligations. This role, granted by states, gives classification societies an undeniable predominance in power relations with the players in the supply chain. Classification societies address problems associated with flag verification and enable states to meet their statutory obligations. As one representative of the classification societies explains, "Port State Control is something we would like to do without. It is a backup to flag state survey, which, if they were working correctly, would render Port State Control useless. But currently, the coastal states are not confident enough that the ships have been surveyed correctly, so they need this back-up system" (CSC, Classification Society). The results indicate an area of uncertainty about how classification societies exercise the delegation of public services and the extent to which they defend the public interest versus their particular interests. Nevertheless, prior research confirms that Port State Control inspections have enabled the industry to lower the costs associated which the risk of detention and loss of ships (Knapp et al., 2011).

The IMO can create regulations, which give classification societies more legitimacy and more markets. Indeed, in the words of a professional of classification societies, "every time there is a new regulation, there is a market, that's for sure. Whether it's big or not, it depends" (CSA, Classification Society). For example, Resolution A.739(18) can also be considered as a tool designed by IMO, not without the support of IACS, to help "maritime administrations in formalising the delegation of authority to organisations, 
for statutory surveys and certification" (Maritime Port Authorities of Singapore, 2002). The present results indicate the duality between the public service mission of classification societies and their business activities, creating conflicts of interest by changing the competitive game.

Overall, these results are consistent with the literature, notably with the works of French and Raven (1959), of Emerson (1962), Cox (2001), Filser (1989) and Filser, and des Garets, V. and Paché, G. (2012). The authors identify the power of reward and punishment, the dependency relationship, the ability to create value and improve processes as major sources of the power from which classification societies benefit massively in their asymmetrical relationships with the supply chain players.

\section{Leadership}

For leadership, the analysis of declarative data was structured into three groups of indicators (see Table 1): (1) Third-party recognition (expertise, legitimacy, creation of a common vision), (2) Leader's weight (size, the scope of activity, client portfolio), (3) Leader's position in the network (central or peripheral, mode of coordination of activities, the role of the pivot to satellites).

\section{Third-party recognition}

The classification certificate is the minimum criterion for a ship to be insured. Classification societies can positively or negatively influence the reputation of shipowners in the market. Indeed, "the classification of ships has a strong impact on the corporate image that shipowners have towards other market players" (International Commission on Shipping, 2000). Thus, a prestigious classification will improve shipowners' recognition of the quality of a shipowner's services. According to shipowners in the Shanghai area, "if the ships are certified by a classification society which is a member of IACS, it will favorably influence the image of the company and of the quality of its services. The choice of classification society depends on what image the shipowner has of themself" (SOB, Shipowner).

However, the position of classification societies can be paradoxical when they provide services to the private sector and the governments which are supposed to govern it. Accordingly, the International Chamber of Shipping explains that there are "conflicts of interest in classification societies working for both the shipowner and the flag state" (International Commission on Shipping, 2000). Classification societies are recognised for their expertise by IMO. "IMO provides the opportunity for classification societies to have a collective voice in providing technical expertise, advice and feedback in the development of the regulatory framework for the global shipping industry" (Sadler, 2013). These results indicate that classifications granted by classification societies represent a major commercial issue for shipowners. The leadership of classification societies is based on their expertise in awarding classification certificates.

In terms of legitimacy, classification societies benefit from recognising States that see them as the actors most able to ensure compliance with ship safety standards, including carrying out technical inspections of ships bearing their flags. So, for example, as one classification company representative explained, "we don't have to employ so many government employees to do the statutory work" (CCS, Classification Society). 
Finally, this recognition by states generates a common repository on maritime safety. For example, classification societies have argued for "recognition of the fact that many flag administrations do not have adequate technical experience, manpower or global coverage to undertake all the necessary statutory inspections and surveys using their own staff' (IACS - International Association of Classification Societies, 2011). As a result, a clear majority of the flag states autonomously decided to delegate their authority to classification societies.

\section{Leader's weight}

The client portfolio of classification societies includes the two most influential players in maritime safety, including shipowners and states (Lissillour, 2017). However, their activities have significant implications for other players who are not considered customers. Their scope of activity starts as soon as the ships are built. For example, classification societies are involved in shipowners' relationships with shipyards. According to a representative of a French shipyard, "there are many things, during the development of the ship, that will give rise to interpretation, give rise to discussion and often the classification company arrives a bit as an arbiter between the shipowner and the shipyards, and technical advisor (is it in accordance with the regulations?)" (SYA, Shipyard). Classification certificates are also used by insurers, clubs that provide coverage for the unlimited risks that traditional insurers are reluctant to insure, charterers, etc.

The leadership of classification societies is enhanced by their ability to encompass many players' activities throughout the life cycle of ships. Although the core business of classification societies is historically maritime safety, they are now large groups with a very diverse portfolio of activities, including certification outside of the maritime, training and consulting arenas. Bureau Veritas, for example, no longer defines itself as a classification company but as a service company which, according to its CEO Didier Michaud-Daniel "has always supported its clients to mitigate risks through our applied expertise in Quality, Health, Environment, Safety, Privacy E Progress" (Bureau Veritas, 2020).

Classification societies are represented by their multiple offices and work with most countries. "Governments were trying to save money and said "we are allowed to delegate, so why don't we use those who are out there for class items and have them do the statutory work as well, and then we don't have to employ so many government employees to do the statutory work" (CSC, Classification Society). Every government around the world has followed this economic reasoning. Although classification societies are very dynamic players, they depend on the states to carry out their work at IMO. "IACS can be a catalyst, but at the IMO we do not have the authority to procedurally even raise a new item in the discussion unless we have at least one Member State as a co-sponsor. We have to persuade a Member State" (CSC, Classification Society).

\section{Leader's position}

Classification societies have a central role for all players in the marine supply chain because certifications are "widely used by all sectors of the marine industry as an indication that a vessel is reasonably fit for the purpose for which it is intended" (Jones, 2003). In addition, classification societies are the organisations that centralise the majority of 
statutory inspections for states: "Much of the statutory work is still carried out by classification societies" (CSA, Classification Society).

The IMO has a central position in the network of classification societies: "It is also the forum where all actors meet for formal and informal discussions. [Our network] helps us at the IMO because we are in contact with other administrations [other than that of our home country], our bureau in Italy is in contact with the Italian administration, so the Italian administration can ask us for advice" (CSA, Classification Society).

The present results are consistent with the literature (Fabbe-Costes, 2010; Defee et al., 2010; Bowersox and Closs, 1996; Ellram and Cooper, 1990; Lavastre et al., 2016). The authors identify sources of leadership such as third-party recognition, the leader's weight and its central position, enabling it to impact the entire chain by coordinating it, impelling a dynamic, performance-generating influence process. By their status, weight and influence, classification societies appear to be undisputed leaders in the chain, holding the attributes of leadership.

\section{Conflict}

For the conflict dimension, the analysis of declarative data was also structured into three groups of indicators (see Table 1): (1) their causes, (2) conflict resolution methods, and (3) management strategies implemented.

\section{Causes}

Maritime stakeholders have an ongoing disagreement over priorities between safety and profit, and competition encourages lobbying to influence the development of regulations and their implementation (Størkersen, 2015). Moreover, classification societies have a particular situation that is often at the root of their conflicts with other players: "We act as auditors for states, but from a classification point of view, we are between shipowners and shipyards, and commercially they have very divergent objectives and interests" (CSC, Classification Society).

Both shipowners and shipyards are concerned about safety, but they may have different solutions for achieving it. In this case, the classification company does the arbitration. The financial implications of classification and verification can be significant for shipowners who can put pressure on classification societies who must, however, rigorously apply existing standards and respond classically: "No, our technical opinion is that, we recognise the disagreement of shipowners because it is expensive, but we will talk to IMO to see what they say" (CSC, Classification Society). Shipowners can then lobby Member States to oppose IACS.

\section{Resolution method}

The present results indicate various conflict resolution methods depending on the types of actors with which classification societies interact. Classification societies dominate the shipowners because they decide whether the vessel can be operated or not. According to shipowners' representatives, "surveyors have the power to decide if the ship reaches the standard. You cannot negotiate. From the point of view of shipowners, the surveyors are high level, we listen to them" (SOB, Shipowner). However, classification societies are more accommodating with the most important shipowners. 
Classification societies and states cooperate because their inspections focus on other safety aspects than those of classification societies. From the port authority's perspective, it is argued that "PSC officers may require the crew to execute a full-scale simulation to show that they know the emergency procedures. Most of our attention goes to the crew rather than the equipment. We generally trust the classification societies for the annual inspections they carry out" (MPAA, Port Authority).

When the texts proposed by the IMO are too vague and are open to many practical interpretations, classification societies propose a unified interpretation of the texts. "Most of our papers are submitted to provide unified interpretations, which is when the text of the IMO is vague, and sometimes that happens because it is the only way the IMO can reach an agreement because they write the words so that everyone can agree to it, since it satisfies their understanding. But then when we go out into the practical world and have to apply that, then we find that the wording is not good enough. It allows for too many different interpretations, so we write unified understandings, and we have hundreds of them, which are all published on our website" (CSC, Classification Society).

\section{Management strategy}

Classification societies adopt different forms of strategy, depending on the importance of the players involved. Thus, if a shipowner chooses to attack a classification company and settle the dispute in court, the outcome of the judgment is generally not favourable towards them. According to shipowners interviewed in groups in Shanghai, they "can sue classification societies after a maritime casualty has occurred because an accident costs the owner a lot of money. The classification society issued the classification certificate, and the accident happened despite the ship having passed the classification survey. But in most cases, the classification societies win" (SOB, Shipowner).

A joint conflict management strategy is reflected in how regulatory texts are drafted and promoted between jurisdictions, IMO and classification societies. This work involves formal and informal discussions during which the parties negotiate a consensus on the draft text. According to the representative of a classification company, "you may need support in a discussion that you are told about in a prior session, such or such has spoken on the subject, and therefore it is of interest and it is relevant to prepare before it is discussed formally. From one assignment to the next, we have a little idea of who is interested, to whom we must explain a given case... either it is done very informally very early on, and you may have to be co-sponsored in the end, or convince other members when sponsoring a paper - or you can be contacted, solicited, to sponsor someone else's paper as well. Finally, in the end, the prior agreements are formal, since you are cosponsor of a document or a proposal. Whether it is something that happens in the corridors or during the coffee break, it is something that works well and is very common" (CSA, Classification Society). Finally, conflict management methods depend both on the strategic importance of actors and show that classification societies have a predominant role.

These results are more contrasted concerning the authors of the literature. While the causes of conflict and their modes of resolution are more about coercion than 
consultation (Angelmar and Waldman, 1975; Dant and Schul, 1992), these results are partially consistent with these authors on conflict management strategies. By their status, weight and influence, classification societies make greater use of coercion management strategies, such as a 'public' actor. The present theoretical contribution demonstrates how classification societies adopt different conflict resolution strategies depending on the importance of the players involved. These strategies oscillate between domination and cooperation, depending on the weight of the actor involved.

\section{Cooperation}

For cooperation, the analysis of declarative data was also structured into three groups of indicators (see Table 1): (1) types of cooperative approaches, (2) major feature and (3) modes of cooperation.

\section{Types of cooperative approaches}

International conventions stipulate that ship operations must be carried out in partnership with classification societies. SOLAS 1974 formally states that "ships shall be designed, constructed and maintained in compliance with the requirements of a classification society, recognised by the Administration, or with applicable national standards of the administration which provides an equivalent level of safety" (SOLAS, Chapter II-1, Regulation 3-1).

Classification societies cooperate with states, which can thus compensate for their lack of skilled manpower for public service, because "When civil servants come to do port state control, they do not have the experience to do the initial survey work" (CSC, Classification Society). Ultimately, "certification, which is a public service performed by the classification societies as authorised agents of many flag states consists of verifying compliance with regulations of vessels registered under these flags" (Bureau Veritas, 2016).

The IMO considers the classification certificates as a tool for operational compliance with international conventions. According to "some conventions, certificates are required to be carried on board ship to show that they have been inspected and have met the required standards. These certificates are normally accepted as proof by authorities from other States that the vessel concerned has reached the required standard, but in some cases further action can be taken" (IMO - International Maritime Organisation, 2019).

\section{Major features}

From shipbuilding to annual reviews, classification societies carry out many activities throughout the life of ships. Likewise, the players in the supply chain carry out many activities to meet the construction and operating standards involved by classification societies. According to a shipyard official, "the classification company issues the certificate of navigation allowance which is a key element for the shipowner to proceed with the receipt of the ship and pay the few million dollars that remain to be paid because 80\% of the shipbuilding is pre-financed by the shipyard" (SYA, Shipyard).

An ongoing process of repetitive activities was formalised by international conventions as early as 1930. As an illustration, the Load Lines Convention states: as according to "the Rules attached to this Convention, ships which comply with the highest standard 
laid down in the rules of a classification society recognised by the Administration are regarded as having sufficient strength for the minimum freeboards allowed under the rules, the Conference recommends that each Administration should request the Society or Societies which it has recognised to confer from time to time with the Societies recognised by other Administrations, with a view to securing as much uniformity as possible in the application of the standards of strength on which freeboard is based" (Recommendation No. 2, 1930).

The IMO relies on classification societies throughout developing technical texts dealing with ship safety because the actors have a common goal, including the creation of texts that are put into practice. "The first time we write a unified interpretation, around $80 \%$ of the unified interpretations are agreed by the whole IMO (which means all the members who are active, those who keep quiet just have to accept what goes on around them) the first time we present them at the IMO" (CSC, Classification Society).

\section{Modes of cooperation}

The cooperation between shipowners and classification societies is operational and technical because the details of the ship orders are co-written with the classification societies. "Classification societies play an important role in negotiations with the operator during construction because in the regulatory part, the order is the subject of a joint order specification between the two. In this order specification, one of the important elements is that the ship will be classified according to the rules of, for example, Bureau Veritas and must comply with its regulations" (SYA, Shipyard).

Sovereignty implies that states can choose between strict or lax control of statutory service providers. This choice has a significant impact on the attractiveness of the country to foreign shipowners. States use classification company certificates to streamline audit efforts by port authorities. "Governments were trying to save money" (SYA, Shipyard) using the resources of classification societies. The port authorities regard international conventions as instruments "to be implemented positively with absolute obedience. We will double-check vessels that are not classified by IACS members twice as frequently. In addition, if they are classified as IACS, we will apply an easier standard than for unclassified IACS vessels" (MPAB, Port Authority).

Classification societies and IMO have forged successful cooperation as it is highly operational and strategic, as stated by the IMO Secretary General's speech states. "The practical work that you do in surveying, assessing and verifying compliance with existing international standards is something the industry and its regulators rely on, every day of the year - and which chimes perfectly with our special focus for 2014 on the implementation of IMO conventions. [ ...] But, moreover, your input, through IACS, in the process of modifying and improving existing standards and, where appropriate, developing new measures, is of immense value" (IMO - International Maritime Organisation, 2014).

These results are in line with the literature (Garrette and Dussauge, 1995; Dornier and Fender, 2001). Because of the status of a public service delegation conferred on classification societies, the latter benefit from strategic alliances with states and with the IMO. These responsibilities lead the various levels of the chain's activities: strategic, tactical and operational. By their status and capacity for influence, classification societies play a central role in cooperation between players in the maritime chain. 


\section{Conclusion}

This research on maritime governance and classification societies arguably demonstrates that these major players play a decisive and paradoxical role in the global maritime supply chain. Moreover, it provides theoretical contributions and managerial implications.

This paper provides theoretical contributions to prior research that have detailed the important role of classification societies for maritime safety but did not address issues related to inter-organisational dynamics (Goh and Yip, 2014). The first contribution of this paper is to provide a new conceptual framework better to grasp the interorganisational dynamics in the supply chain. With the power to reward or sanction, mobilise resources, create an appropriate added value, classification societies play a central role in the governance of international maritime safety. Their leadership enables them to play a central, decisive and paradoxical role in the functioning of the shipping market. These companies are recognised with the legitimacy conferred by the public service delegation for their expertise; they create a common vision. Their size, client portfolio and scope of activities place them at the heart of the network, coordinating activities and acting as a central agent to all actors, with a dual capacity of market regulation and a competitive position. In conflict situations between players in the shipping market, classification societies are the ideal actors to manage and resolve them. Classification societies adopt different forms of conflict resolution strategies depending on the relative power of the players involved. These strategies oscillate between domination and cooperation, depending on this power. Finally, in cooperation between players in the maritime transport market, classification societies facilitate their management and coordination of activities. Cooperation occurs on strategic (partnerships and alliances) and operational (coordination) levels.

The second theoretical contribution of this paper is to tackle the subject with qualitative methods. Indeed, prior research studies have been studied classification societies mostly with quantitative methodologies to measure the impact of variables such as the flag of registry the age, ship size and type and class on maritime safety (Knapp and Franses, 2007b; Cariou et al., 2007, 2008; Cariou and Wolff, 2011; Knapp et al., 2011; Bijwaard and Knapp, 2009). These studies provided interesting measurement with substantial implications, but our qualitative analysis could reveal new aspects of the interplay between actors. The power, leadership, conflict, and cooperation behaviours that classification societies maintain with their markets are marked by a duality oscillating between regulatory actions and competitive behaviour, which is a paradoxical position of these central institutions in the maritime chain. The implications of this data in the initial field should ultimately provide a holistic view of the present research object.

Third theoretical contribution: this research underlines that prior research analysed the lack of trust amongst stakeholders, which has created an environment that fomented new safety inspections (Knapp and Franses, 2010). This research study contributes by providing a complete understanding of the inter-organisational dynamics around classification societies. More recent works based on Bourdieu's thinking (Lissillour and Bonet-Fernandez, 2018, 2020) shed much light on the power struggle in the supply chain from a new perspective. However, unlike the present paper, they could not provide a fair account of the cooperation and mutual interest in problem-solving that this behaviourist analysis allowed. 
Finally, from a praxeological point of view, these research outcomes generate managerial implications for shipping companies because they shed new light on the unique role of classifications societies. This role has serious consequences in the definition and implementation of maritime safety regulations and standards and, more broadly, in how shipping companies design logistics strategies according to changing international logistics chains. The multiple perspectives provided by the behaviourist approach allow maritime transport practitioners to understand better the decisive and paradoxical role of classification societies and public bodies to nourish reflections on maritime safety management. For example, port authorities may periodically (every five years, for instance) control the ships themselves, not via a Recognised Organisation, to verify compliance with statutory requirements to reduce eventual conflict of interest. Such solutions may allow for control of classification societies' work while helping public authorities to maintain a skilled workforce with updated technical expertise and thus reduce their operational and regulatory dependence on classification societies.

This study has methodological limitations regarding the dataset, including mainly French and Chinese elements, and excludes other geographies such as the USA or Africa. Even though this paper describes the general dynamics of a global industry, future studies may compare practices between geographies and eventually identify different findings. Since they cover more than $90 \%$ of the market, this study focused on classification societies that are IACS members, but adding non-IACS societies in the analysis may provide additional insights into a market with specific practices. The conceptual framework developed in this paper follows a deductive and systemic approach that could be applied to other maritime safety agents. Future studies may follow this approach by reviewing the literature concerning the specific role of other agents before adjusting the indicators selected in this paper and eventually identify new ones, notably abstract invariants that could be added to the framework (Van Campenhoudt and Quivy, 2011). Further research could look at maritime safety from another perspective, such as the role of IACS as the meta-organisation of classification societies (Carmagnac and Carbone, 2019) and the notion of service in the supply chain industry (Prakash, 2011).

\section{APPENDIX}

\section{FOCUS GROUP QUESTIONS}

1. What is your opinion about maritime safety at the world level? Is it satisfactory or not?

2. What are the problems with classification companies?

3. Shipowners are the customers of classification companies. Does this create conflict of interests?

4. Shipowners have a substantial economic ressources in comparison to other actors, does this influence maritime safety?

5. Classification companies know most technical details about the vessels. How do they use this type of advantage?

6. Classification societies are now authorized to do statutory duties on behalf of maritime administrations all over the world. What do you think about it?

7. Which group is doing the highest lobbying at the International Maritime Organization in respect to maritime safety? 


\section{Are they some actors who loose credibility in maritime safety?}

9. Are there loopholes in maritime safety?

\section{To whom do these loopholes benefit?}

\section{Acknowledgements}

This version of the article benefited from the comments made during the conference presentation (2021 World of Shipping Portugal). It also benefited from the rich comments and suggestions of the anonymous reviewers. We would like to thank them warmly.

\section{Authors' contributions}

Both authors have equally contributed to the article.

\section{Authors information}

Francois FULCONIS is an Associate Professor of Strategic and Logistics Management at the University of Avignon (AU), France. He is an associate member of LBNC (AU) and a permanent member of CRET-LOG (Aix-Marseille University, AMU). His research interests include strategic partnerships, network structures, supply chain management and the logistics service providers industry. He has published more than 180 reports, a book, book chapters and papers in academic journals and international conference proceedings.

Raphael LISSILLOUR is an Associate Professor of Strategy and Management at IPAG Business School. He is in charge of developing international academic partnerships and is the director of the Doctorate in Business Administration program at IPAG Business school. He holds a PhD degree from Jilin University in China where he conducted a doctoral research on the global governance of maritime safety. His research focuses on sociological approaches to supply chain management and information systems.

\section{Funding}

No fundings.

\section{Availability of data and materials}

The datasets generated during and/or analysed during the current study are not publicly available due to interviewees preference but are available from the corresponding author on reasonable request.

\section{Declarations}

\section{Competing interests}

The authors declare that they have no competing interests.

\section{Author details}

${ }^{1}$ Avignon University (AU), research laboratories: LBNC (AU) and CRET-LOG (AMU), Avignon, France. ${ }^{2}$ IPAG Business School, PostDoc at the École Polytechnique (i3-CRG), Paris, France.

Received: 26 February 2021 Accepted: 28 June 2021

Published online: 16 July 2021

\section{References}

Alderton T, Winchester N (2002) Flag states and safety: 1997-1999. Marit Policy Manag 29(2):151-162. https://doi.org/10.1080/ 03088830110090586

Angelmar R, Waldman C (1975) Les Conflits dans les canaux de distributions. Rev Fr Gest 1:57-68

Bijwaard G, Knapp S (2009) Analysis of ship life cycles - the impact of economic cycles and ship inspections. Mar Policy 33(2): 350-369. https://doi.org/10.1016/j.marpol.2008.08.003

Bindel, S. (2019). "Classification, sociétés de", Encyclopædia Universalis. URL: http://www.universalis-edu.com/encyclopedie/ societes-de-classification/ accessed on November 12th, 2019

Bonet-Fernandez D (2008) Réflexions sur les relations inter-organisationnelles: du dépassement de l'antagonisme conflitcoopération à l'émergence de nouvelles démarches collaboratives. Habilitation à Diriger des Recherches en Sciences de Gestion. Université de la Méditerranée, Aix-en-Provence

Bonet-Fernandez D, Boissinot A (2012) Quel leadership pour les prestataires de services logistiques dans la supply chain de I'automobile? Logistique Manag 20(2):31-40

Bowersox D, Closs D (1996) Logistical management: the integrated supply chain process. McGraw-Hill, New York (NY) Bowersox D, Cooper M, Lambert D, Taylor D (1980) Management in marketing channels. McGraw-Hill, New-York (NY) Brooks M (1996) The privatisation of ship safety. Marit Policy Manag 23(3):271-288. https:/doi.org/10.1080/03088839600000089 Bureau Veritas (2020). Mission, ambition. URL: https://group.bureauveritas.com/fr/groupe/mission-ambition, Accessed on August $1^{\text {st }}, 2020$

Van Campenhoudt L, Quivy R (2011) Manuel de recherche en sciences sociales. Du nod, Paris

Cariou P, Mejia M, Wolff F-C (2007) An econometric analysis of deficiencies noted in port state control inspections. Maritime Policy Manag 34(3):245-260

Cariou P, Mejia M, Wolff F-C (2008) On the effectiveness of port state control inspections. Transport Res E 44(3):491-503. https://doi.org/10.1016/j.tre.2006.11.005

Cariou P, Wolff F-C (2011) Do port state control inspections influence flag-and class-hopping phenomena in shipping? Transport Econ Policy 45(2):155-177

Carmagnac L, Carbone V (2019) Making supply networks more sustainable 'together': the role of meta-organisations. Supply Chain Forum 20(1):56-67. https://doi.org/10.1080/16258312.2018.1554163 
Ceyhun G (ed) (2020) Handbook of research on the applications of international transportation and logistics for world trade. IGI-Global, Hershey (PA). https://doi.org/10.4018/978-1-7998-1397-2

Christopher M (1992) Logistics and supply chain management: creating value-adding networks. Prentice Hall, Harlow

Cox A (1999) Power, value and supply chain management. Supply Chain Manag 4(4):167-175. https://doi.org/10.1108/13 598549910284480

Cox A (2001) The power perspective in procurement and supply management. J Supply Chain Manag 37(1):4-7. https://doi. org/10.1111/j.1745-493X.2001.tb00093.x

Cyert R, March J (1963) A behavioral theory of the firm. Prentice Hall, Englewood Cliffs (NJ)

Dant R, Schul P (1992) Conflict resolution processes in contractual channels of distribution. J Mark 56(1):38-54. https://doi. org/10.1177/002224299205600105

Davis-Sramek B, Thomas RW, Fugate BS (2018) Integrating behavioral decision theory and sustainable supply chain management: Prioritising economic, environmental, and social dimensions in carrier selection. J Bus Logist 39(2):87-100. https://doi.org/10.1111/jbl.12181

Defee C, Stank T, Esper T (2010) Performance implications of transformational supply chain leadership and followership. Int J Phys Distribution Logistics Manag 40(10):763-791. https://doi.org/10.1108/09600031011093205

Denzin NK, Lincoln YS (eds) (2017) The Sage Handbook of Qualitative Research. 5th ed. Sage Publications, London

Dominguez-Péry C, Vuddaraju L, Duffour V, Eydieux J, Tassabehji R (2021) Risk and safety in maritime transport: a review and agenda for research, 2021 World of Shipping Portugal - An International Research Conference on Maritime Affairs, Portugal, 28-29 January, pp 1-21

Dornier P-P, Fender M (2001) La Logistique globale. Éditions d'Organisation, Paris

Ellram L, Cooper M (1990) Supply chain management, partnerships, and the shipper-third-party relationships. Int J Logist Manag 1(2):1-10. https://doi.org/10.1108/95740939080001276

Emerson R (1962) Power-dependence relations. Am Sociol Rev 27(1):31-41. https://doi.org/10.2307/2089716

Fabbe-Costes N (2010) Réussir l'intégration des chaînes logistiques, Encyclopédie Techniques de l'Ingénieur, Ref. AG5240. Éditions Techniques de l'Ingénieur, Paris

Ferrer M (2004) La Responsabilité des sociétés de classification. Aix-en-Provence: Presses Universitaires d'Aix-Marseille (PUAM)

Filser M (1989) Canaux de distribution : description, analyse, gestion. Vuibert, Paris

Filser M, des Garets V, Paché G (2012) La Distribution: organisation et stratégie, 2e éd. EMS - Éditions Management \& Société, Caen

French J, Raven B (1959) The bases of social power. In: Cartwright D (ed) Studies in social power. University of Michigan Press, Ann Arbor (MI), pp 150-167

Fulconis F, Roveillo G (2017) L'Intermédiation logistique dans le pilotage des chaînes multi-acteurs : proposition d'une grille d'analyse. Manag Avenir 8(98):163-189

Garrette B, Dussauge P (1995) Les Stratégies d'alliance. Éditions d'Organisation, Paris

Gino F, Pisano G (2008) Toward a theory of behavioral operations. Manuf Serv Oper Manag 10(4):676-691. https://doi.org/1 $0.1287 / \mathrm{msom} .1070 .0205$

Goh LB, Yip TL (2014) A way forward for ship classification and technical services. Asian J Shipping Logistics 30(1):51-74. https://doi.org/10.1016/j.ajsl.2014.04.003

Goldman R (1966) A theory of conflict processes and organisational offices. J Confl Resolut 10(3):335-340

Hoffmann N, Stahlbock R, Voß S (2020) A decision model on the repair and maintenance of shipping containers. J Shipping Trade 5(1):1-21

Hormann $\mathrm{H}$ (2006) Classification societies - what is their role, what is their future? WMU J Marit Aff 5(1):5-16. https://doi.org/1 $0.1007 / \mathrm{BF} 03195078$

IACS - International Association of Classification Societies (2011). Class, what, why, and how? URL: http://www.iacs.org.uk/ media/3785/iacs-class-what-why-how.pdf, accessed on February 1st, 2020

IMO - International Maritime Organisation (2014). Nouvelle réglementation de lOMM, objectifs et attentes de lindustrie du transport futur, Discours liminaire de Koji Sekimizu, Secrétaire général, Organisation Maritime Internationale. URL: http:/www.imo.org/fr/MediaCentre/ SecretaryGeneral/SpeechesByTheSecretaryGenera/Pages/ACScouncil2014.aspx. Accessed on January 15th, 2019

IMO - International Maritime Organisation (2019). Adopting a convention, Entry into force, Accession, Amendment, Enforcement, Tacit acceptance procedure. URL: http://www.imo.org/en/About/Conventions/Pages/Home.aspx. Accessed 31th May, 2019

International Commission on Shipping (2000). Ships, slaves, and competition. Article 2.28. URL: http://seafarersrights.org/lega I_database/ships-slaves-and-competition/. Accessed on September 30th, 2019

Jones E.H. (2003). Otto candies, L.L.C v. Nippon Kaiji Kyokai Corp. United States court of appeals, fifth circuit. URL: http://casela w.findlaw.com/us-5th-circuit/1330625.html. Accessed on October 2nd, 2019Kaufmann L, Meschnig G, Reimann F (2014) Rational and intuitive decision-making in sourcing teams: effects on decision outcomes. J Purch Supply Manag 20(2): 104-112. https://doi.org/10.1016/.jpursup.2014.03.003

Kaufmann L, Wagner CM, Carter CR (2017) Individual modes and patterns of rational and intuitive decision-making by purchasing managers. J Purch Supply Manag 23(2):82-93. https://doi.org/10.1016/j.pursup.2016.09.001

Knapp S, Bijwaard G, Heij C (2011) Estimated incident cost savings in shipping due to inspections. Accid Anal Prev 43(4): 1532-1539. https://doi.org/10.1016/j.aap.2011.03.005

Knapp S, Franses PH (2007a) A global view on port state control: econometric analysis of the differences across port state control regimes. Marit Policy Manag 34(5):453-482. https://doi.org/10.1080/03088830701585217

Knapp S, Franses PH (2007b) Econometric analysis on the effect of port state control inspections on the probability of casualty. Mar Policy 31(4):550-563. https://doi.org/10.1016/j.marpol.2006.11.004

Knapp S, Franses PH (2008) Econometric analysis to differentiate effects of various ship safety inspections. Mar Policy 32(4): 653-662. https://doi.org/10.1016/j.marpol.2007.11.006

Knapp S, Franses PH (2010) Comprehensive review of the maritime safety regimes: present status and recommendations for improvements. Transp Rev 30(2):241-270. https://doi.org/10.1080/01441640902985934

Koenig G (1996) Management Stratégique. Nathan, Paris

Kopela S (2017) Making ships cleaner: reducing air pollution from international shipping. Rev Europ Comparative Int Environ Law 26(3):231-242. https://doi.org/10.1111/reel.12220 
Kretschmann L (2020) Leading indicators and maritime safety: predicting future risk with a machine learning approach. J Shipping Trade 5(1):1-22

Langlais P (2018) Sécurité maritime et intégration européenne. Éditions Bruylant, Bruxelles

Latrech B (2004) Les Sociétés de classification des navires : la sécurité en question, Thèse de doctorat en Histoire du Droit. Université de Perpignan, Perpignan

Lavastre O, Carbone V, Ageron B (dir.) (2016). Les Grands auteurs en Logistique et Supply Chain Management. Caen: EMS Éditions Management \& Société. https://doi.org/10.3917/ems.lavas.2016.01

Li KX, Wonham J (1999) Who is safe and who is at risk: a study of 20-year-record on accident total loss indifferent flags. Maritime Policy Manag 26(2):137-144. https://doi.org/10.1080/030888399286961

Lissillour R (2017) The rise of a transnational private actor in maritime safety: Toward a practice-based theory of non-state actors in global governance, thesis in political science, may 31. Jilin University, Changchun

Lissillour R, Bonet-Fernandez D (2018) PSL et gouvernance de la sécurité maritime : apports de la théorie de Bourdieu. Logistique Manag 26(4):214-228. https://doi.org/10.1080/12507970.2018.1527731

Lissillour R, Bonet-Fernandez D (2020) The balance of power in the governance of the global maritime safety: the role of classification societies from a habitus perspective, Supply Chain Forum: An International Journal, pp 1-13

Lissillour R, Bonet-Fernandez D, Fulconis F (2019) The classification societies, an obstacle or an accelerator to international maritime safety? 10th IRMBAM - International Research Meeting in Business and Management, IPAG BS, Nice, 08-10 July, pp 1-17

Lissillour R, Fulconis F, Bonet-Fernandez D (2021a) Maritime safety beyond ports: an issue of global governance between land and sea, Chapter 12. In: Cros S, Lerique F (eds) Les ports en France. Quelle stratégie portuaire pour un développement de l'activité ? Éditions ESKA, Paris, pp 157-185

Lissillour R, Fulconis F, Psaraftis HN (2021 b) A nomos perspective of shipping service industries, European Review of Service Economics and Management, (2) [forthcoming]

Mantel SP, Tatikonda MV, Liao Y (2006) A behavioral study of supply manager decision-making: factors influencing make versus buy evaluation. J Oper Manag 24(6):822-838. https://doi.org/10.1016/j.jom.2005.09.007

Marasi News (2017). Shipping: the role of classification societies. URL: https://www.marasinews.com/classification/shippingrole-classification-societies. Accessed on December 8th, 2019

March J, Simon H (1958) Organizations. John Wiley \& Sons, New York (NY)

Maritime Port Authorities of Singapore (2002). MPA Signs Instruments with Nine Classification Societies. URL: http://www. mpa.gov.sg/web/portal/home/media-centre/news-releases/detail/12d9e632-f030-4dc5-a007-d16019e02aec. Accessed on October 19th, 2019

Mentzer J, Dewitt W, Keebler J, Min S, Nix N, Smith C, Zacharia Z (2001) Defining supply chain management. J Bus Logist 22(2):1-25. https://doi.org/10.1002/j.2158-1592.2001.tb00001.x

Molenaar E (2014) Options for regional regulation of merchant shipping outside IMO, with particular reference to the Arctic region. Ocean Develop Int Law 45(3):272-298. https://doi.org/10.1080/00908320.2014.929474

Paché G, Spalanzani A (2007) La gestion des chaînes logistique multi-acteurs: perspectives stratégiques. Presses Universitaires de Grenoble (PUG), Grenoble

Porter M (1986) L'avantage Concurrentiel. Interéditions, Paris

Prakash G (2011) Service quality in supply chain: empirical evidence from Indian automotive industry. Supply Chain Manag 16(5):362-378. https://doi.org/10.1108/13598541111155866

Rahman N, Salleh N, Najib A, Lun V (2016) A descriptive method for analysing the Kra Canal decision on maritime business patterns in Malaysia. J Shipping Trade 1(13):1-16

Raynaut, J. (2019). Navigation: les sociétés de classification au cœur de la sécurité maritime. Actualité Maritime. URL: https://a ctumaritime.com/2019/09/30

Robert S, Marlow PB (2002) Casualties in dry bulk shipping (1963-1996). Mar Policy 26(6):437-450. https://doi.org/10.1016/S03 08-597X(02)00024-6

Roveillo G (2015) Approche béhavioriste de l'intermédiation logistique : le rôle dynamisant du prestataire de services logistiques, Thesis in Management Sciences, CRET-LOG. Aix-Marseille University (AMU), Aix-en-Provence

Sadler P (2013) The role of classification societies, recognized organizations and IACS. Bulletin IACS 108(3):86-88

Salas E, Rosen MA, DiazGranados D (2010) Expertise-based intuition and decision making in organizations. J Manag 36(4): 941-973. https://doi.org/10.1177/0149206309350084

Schopler J (1965) Social power. Adv Exp Soc Psychol 2(2):177-218. https://doi.org/10.1016/S0065-2601(08)60106-9

Simon H (1947) Administrative behavior - a study of decision-making processes in administrative organizations. The Free Press, New York

Stern L, El-Ansary A (1977) Marketing channels. Prentice-Hall, Englewood Cliffs

Størkersen KV (2015) Survival versus safety at sea. Regulators' Portrayal Paralysis Safety Regulation Development. Safety Science 75:90-99

Talley W (1999) Determinants of ship accident seaworthiness. Int J Marit Econ 1(2):1-14. https://doi.org/10.1057/ijme.1999.9

Bureau Veritas (2016). Classification. URL: http://www.bureauveritas.com/home/ our-services/classification, Accessed on September 1st, 2019

Wang J (2001) The current status and future aspects in formal ship safety assessment. Saf Sci 38(1):19-30. https://doi.org/10.1 016/S0925-7535(00)00052-7

\section{Publisher's Note}

Springer Nature remains neutral with regard to jurisdictional claims in published maps and institutional affiliations. 